\title{
The hated city, from transcendence to immanence
}

\author{
Ódio à cidade: da transcendência à imanência
}

Jacques Lévy [I]

\begin{abstract}
The myth of Babel (Genesis 11, Old Testament) is an early and pure example of using urbanity and globality as an evidence of hubris. The accurate analysis of this short text shows that rejection of urbanity is not the effect of a vague metaphor; rather, it is based on the observation that city-making represents the perfect expression of humanity's capability for carrying out modest yet ambitious autonomous plans. The statement that urbanisation and the cooperation of all humans would be a $\sin$ is less easy to maintain today, but fresher libertarian or neonaturalist ideologies, replacing transcendence by immanence, have emerged and achieved a historical continuity with mainstream religious demands. Reluctance towards a possible emancipation through selforganised spatial arrangements continues to connect urban agency to a more general antisocietal and anti-human stance.
\end{abstract}

Keywords: Babel; urbanity; transcendence; immanence; libertarian; neonaturalist.
Resumo

O mito de Babel (Gênesis 11, Velho Testamento) é um exemplo antigo e puro do uso da urbanidade e do globalismo como evidências de húbris. A análise apurada desse texto curto mostra que a rejeição da urbanidade não é efeito de uma metáfora vaga; baseia-se na observação de que a fabricação das cidades representa a expressão perfeita da capacidade humana de realizar planos autônomos simples, mas, ao mesmo tempo, ambiciosos. A afirmação de que a urbanização e a cooperação de todos os seres humanos seriam um pecado não é tão fácil de ser mantida hoje em dia, mas ideologias libertárias ou neonaturalistas mais recentes, que substituíram transcendência por imanência, surgiram e conseguiram alcançar uma continuidade histórica com as demandas religiosas predominantes na atualidade. A relutância em relação a uma possível emancipação por meio de arranjos espaciais auto-organizados continua a conectar a atividade urbana a uma postura antissocietal e anti-humana mais geral.

Palavras-chave: Babel; urbanidade; transcendência; imanência; libertário; neonaturalista. 
There is a certain continuity in the presence of anti-urban attitudes in a longduration historical sequence. The threereligion monotheist myth of Babel shows that, as early as Antiquity, when the urban population rate was very low, the social process of city-making was addressed as a good example of hubris, the human challenging of God's prerogatives. This period started with the writing of the Old Testament (circa $5^{\text {th }}$ century BC) and continued as far as a literal reading of the scriptures prevailed - that is, for some believers, till now -, and from then on, there has been a divine, vertical 'geography' of discontent based on the discontent with a certain geography. Its target has been the city as a spatial choice, a spatial configuration, and a spatial way of society-making.

In this article, a daring time leap is performed and the paths of a complex transformation of the myth into contemporary ideologies and practices are identified. This long-range perspective makes visible the combination of continuity and discontinuity in the history of anti-urban ideologies.

In spite of major changes in social worlds and in their self-representations, particularly the progressive, pervasive vanishing of the effective presence of a God in Western societies, the resilience capability of anti-urban attitudes is actually striking. This apparent permanence is enabled by a transformation in the underpinning framework in which the hatred for cities can survive and even thrive in yet so different contexts, as if this negative relation to urbanity had jumped from a vehicle into others, which were conveniently available on the road. This fresh framework is dual: a nature-worshipping, anti-humanist religiosity and a libertarian, anti-societal inhabiting choice. In both cases, immanence takes over from transcendence, conserving the same rejection of any self-organisation of the social world. The main change among these attitudes is that transcendence has been replaced by immanence, while the rejection of urban selfdevelopment, human autonomy, and of the Enlightenment remains at a comparable level.

However, is it possible that this resemblance between ancient and contemporary speeches and acts results only from the fallacious interpretation of a non-significant, superficial coincidence? The question obviously deserves to be asked. The interpretation proposed here is that the social environments and the actors' motives have certainly changed; nevertheless, in both situations, hatred for the city has to do with the emergence of ethics as a multistage historical process. In Ancient times, the necessity for moral commandments supposedly external to human agency was seen as incompatible with a non-hierarchical plan of urbanisation and globalisation that Babel epitomised. Today, the freedom-responsibility-equality triad that turns out to be pivotal in urbanity and urbanism is the keystone of an inprogress ethical turn (Lévy, 2021) which, in certain sections of the society, generates bitterness and anger. Contexts and reasons are different, but the nearness between the urban experience and certain societal patterns lasts. 


\section{Genesis 11: condemning cities as a self-organised human spatiality}

What can be said in the scope of social science about the myth of Babel (Genesis 11, Old Testament) cannot come from a transhistorical approach to a text; rather, it must derive from a multi-context analysis.

\section{A social science reading}

Reading a text that was written in the Eastern Mediterranean area between the $8^{\text {th }}$ and the $2^{\text {nd }}$ century $B C$ and whose diffusion has been extraordinarily vast in space and time raises a non-trivial question about a relevant set of interpretations. When we look at the text itself as a production located in a specific historical and geographical situation, relating the speech to then-existing realities must be performed with caution. The cities of that period, for example, were not as complex and populous as they are today, and this may significantly change the substance of any urban allegory. However, conversely, some of the universal characteristics of urbanity and urbanisation were already present at that time and we can take on the choice of using the word 'city' to designate both Nebuchadnezzar II's Babylon and contemporary Pearl River Delta urban area. There is nothing obvious here and this choice supposes, in the background, a strong and accurate theory of urbanity (see Lévy, 1994; Lévy \& Lussault, 2013), able to spot similarities and dissimilarities between cities that are so different from each other.
As for the long genealogy of this text's reception, we have to prevent the risk of decontextualization. Pulling out a human production from the conditions of this production and of the diffusion of the product is a classic claim of religious organisations and activists about their 'scriptures', but the very opposite of scientific methodology.

Moreover, pretending that each period could legitimately find part of the truth in the same text is slippery. Of course, scientists find news paths of interpretation today, but this does not mean that an old text would be less submitted to historical mutations than any social reality. In religious studies, we often face resistance from theologists who try to contain the obsolescence of their speeches by proposing new significations to ancient statements. Their implicit reasoning is that the 'literal' reading of the scriptures would wrongly ignore that God had to speak to the poor, ignorant people of those times and had to adjust the truth (He, of course, perfectly knew it), creating a pedagogic material in order to be understood. Nowadays, sophisticatedly educated as we are, we can, at last, reach the very substance of His thought. For instance, Creation would not have taken place in six days but in six geological periods. As we will see in the case of Babel, some recent maverick interpretations have not hesitated to erase any conflict between God and mankind.

Those theologists continue, in adverse conditions, a long tradition (particularly massive in the Catholic Christianity, the Shiite Islam, and the Rabbinic Judaism) of interposing their views as an official interpretation between a text and its readers. They carry their creationist burden and they perform 
their political job. We take our scientific commitment seriously.

In this perspective, what can we say about Genesis 11's text? The question is twofold: what is said about humans, societies and cities? What is God's response to this description?

\section{The Sin of Urbanity}

\section{Genesis 11:1}

Now the whole world had one language and a common speech.

"Now" shows this is a new era, in comparison to previous episodes of the Genesis. The possibility of unlimited language interactions is a condition for a society to exist.

Mutual understanding is a pivotal element in the emergence of a Worldsociety, as it is a tool for transactions, for affective interactions, for cooperative creations and productions, and for ethical or political debates.

Genesis 11:2

As people moved eastward, they found a plain in Shinar and settled there.

Genesis 11:3

They said to each other, "Come, let's make bricks and bake them thoroughly." They used brick instead of stone, and tar for mortar.

Thrift is typical of urban agency, and more generally of human development. In the text, there is no trace of luxury, vice or any material corruption - nothing comparable with the Golden Calf worship (Exodus 32) or with Sodom's and Gomorrah's behavioural sins (Genesis 18-19).

Furthermore, doing more with less is a possible abstract for the paradigm of sustainable development. Back at that time (pre-Roman Middle-East oasis societies), the city quickly turned out to be a good compromise between the relative lightness of immobilised infrastructures and the potential permanence of the human settlement it enables. The major immaterial and mental dimensions of a city appear in this narrative of an easy, low-cost construction.

"They said to each other": neither autocrats nor an internal hierarchy or power are mentioned. What is important for the authors is to focus on a collective endeavour. Never in the text is this cohesion of the group said to be due to a constraint or an exogenous principle imposed on its members: the very existence of the society is to be found in its own plan and in the performance that allows to achieve it. There is us but no them; therefore, there is nothing communal in the way human sociality is described.

\section{Genesis 11:4}

Then they said, "Come, let us build ourselves a city, with a tower that reaches the heavens, so that we may make a name for ourselves; otherwise we will be scattered over the face of the whole earth."

"Let us build ourselves a city": the principle of self-organisation of the human world and of the autonomy of humans before God is the first element of the hubris that motivates God's reaction. The protagonist is clearly us. God's rival is not a set of individual behaviours like what can be found in frequent narratives of the Old Testament. In the case of Babel, the us' agency does not generate a collective punishment for sins committed by an individual or a small group; rather, it brings about the punishment of a collective: humans as a society.

"Make a name for ourselves" is generally interpreted as the idea of a transgenerational, stable collective 
identity. This is the second element: the long-lasting human presence enabled by a city, which can be seen as an alternative to nomadism, along with farming. This opposition is thematised in a previous section $(4,1-15)$ of the Genesis: the criminal farmer Cain may represent, like Babel, the threat to the human submission to God that is posed by the potentially unlimited self-development of a given place (a cultivated field or a city). "Make a name for ourselves" would mean conquering a self-sufficient productive autonomy.

What exactly does Babel's plan consist of? The high-rise tower described by Genesis 11 evokes some omens (oracles) in the Shumma Alu, the Paleo-Babylonian sacred text series ( $11^{\text {th }}$ century $B C$ ): "If a city lifts its head to the midst of heaven, that city will be abandoned" (1.15), and "If a city rises like a mountain peak to the midst of heaven, that city will be turned to a ruin" (1.16). Mesopotamian cities were often built on hills, with the temple on the highest ground. The wording of these omens, understood in the context of the omen series, is essentially that of a rivalry between cities that could lead to war and destruction. Accordingly, Peter J. Harland (1998) has shown that what annoyed God was not exactly the height of the tower. In that context, many ziggurats were described as reaching the heavens. "God's action therefore concerns the unity of the place", he sums up (p. 529). What is at stake would then be the (horizontally) spatial productivity of the urban space rather than its physical verticality.

\section{Genesis 11:5}

But the Lord came down to see the city and the tower the people were building.

"The city and the tower" form a whole: a spatial system and a temporal process. The urban expression of hubris is made indubitable here because the humans are able to make something consistent and stable as if they were God.

\section{Genesis 11:6}

The Lord said, "If as one people speaking the same language they have begun to do this, then nothing they plan to do will be impossible for them.

Thanks to their interaction tools, societies are able to perform collaborative works, which extends the limits of their efficiency. The absence of predefined limits, that is, the possibility of a long-term cumulative development, is comparable to the idea of Creation, a prerogative of God.

\section{Genesis 11:7}

Come, let us go down and confuse their language so they will not understand each other."

Genesis 11:8

So the Lord scattered them from there over all the earth, and they stopped building the city.

\section{Genesis 11:9}

That is why it was called Babel - because there the Lord confused the language of the whole world. From there the Lord scattered them over the face of the whole earth.

The nature of the punishment provides the reason of this act. The substance of the response is the destruction of the prerequisites that had allowed the construction of the tower-city: a joint project through a common language. The outcome, the scattering of mankind, is the opposite of what characterises urbanity: the concentration of a maximal number of social realities in a minimal extent. 


\section{Fast track: from transcendence to immanence}

The legacies of Babel deserve an in-depth diachronic inquiry (Lévy, 2019). If, more modestly, we take the liberty to jump over centuries, we can try to analyse the dynamics of the Babel myth on the contemporary public stage.

\section{A Thick Legacy}

In the diagram (Figure 1), some ideological movements, linked or not to the JewishChristian-Muslim tradition, can be identified. All of them are part of the ethical-political dimension of intellectual history. The history of the social sciences, from Max Weber to Henri Lefebvre and Jane Jacobs, was left aside.

Figure 1 - The Anti-Babel Constellation

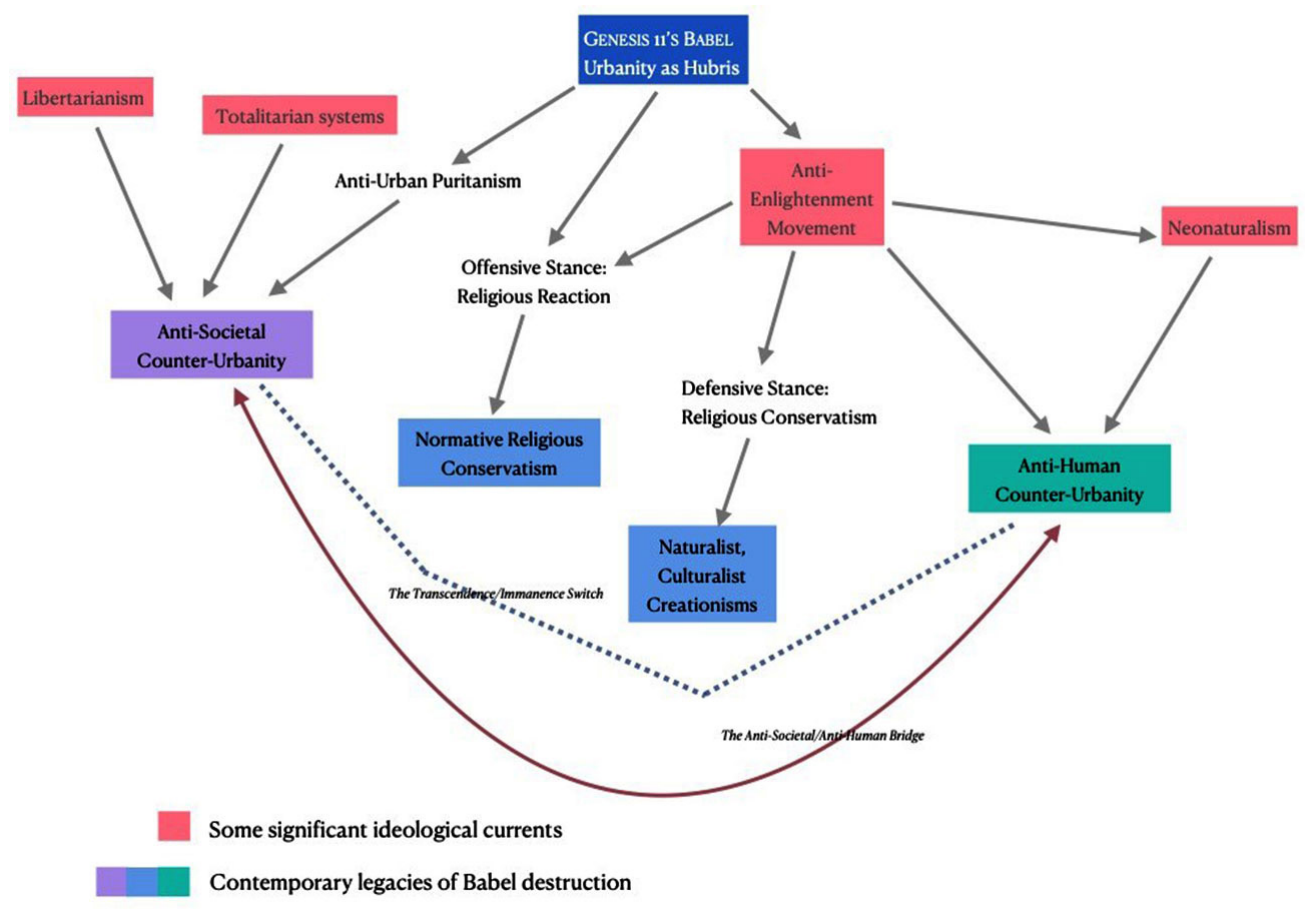




\section{A weakened yet enlarged network}

First, let's have a look at the central part of the diagram.

Leon R. Kass (1989) analyses God's discontent with Babel. He enumerates five "failures" of which the humans are guilty and which justify the destruction of the Tower:

1) They erase the distinction between the human and the natural or divine.

2) They deny their mortality.

3) They focus on self-creation and neglect the moral standards required to govern technique.

4) Their words are totally devoted to technical communication and do not reveal the world and the truth anymore.

5) The previous four failures are made invisible and the disease becomes incurable.

It is clearly a justification of transcendent morals from an anti-progress base, but with a Heideggerian anti-technique point of view rather than a viewpoint from a classic religious dogma. God should punish again but it is too late. In this approach, the city is a context, a set, a setting, a frame; urbanity and globality are just ignored as such. To Kass, speaking of a city is a simple way to evoke the Platonic cave where mankind could potentially be trapped.

The author of this article writes about religion but is also a biologist and a bioethicist hired by George W. Bush in 2001 to create the President's Council on Bioethics, later disbanded by Barack Obama. Embryo research, stem cells and therapeutic cloning were the main topics of this Council and Kass systematically took restrictive positions. Kass (Wikipedia, 2020) places "special value on the natural human cycle of birth, procreation and death" and views death as a "necessary and desirable end" for humans and human aspirations. He views human mortality as a blessing in disguise, and he has shown his bold opposition to increasing human life expectancy in pursuit of "biological immortality".

Kass is part of the anti-Enlightenment mainstream religious 'party' and his rejection of human self-transcendence and emancipation is loud and clear. It is all the more significant that he attributes little interest to the urban referent used in Genesis 11's hubris allegory. To Kass, the city is simply an imaged word to mean an autonomous society and does not convey any extra meaning.

Theodore Hiebert (2007) represents another variant of the 'support' to God's action. Two main differences in relation to Kass' approach can be observed in his interpretation of the myth. Firstly, he sees the destruction of the Tower as a happy event and secondly, he concludes that there is nothing normative in God's stance; it is just a description of the cultural diversity that flourishes in mankind.

However, Theodore Hiebert should not be considered as a maverick Christian thinker. Besides his erudite work, he is also the co-author of God's Big Plan (2019), "the perfect introduction for children ages 1-3 to the wonderful and inspiring diversity of the world God created." Therefore, he could be classified as a culturalist and naturalist Creationist. For him and other converging authors, it has become difficult to sell to the general audience a punishing God. Hubris and its consequences have been removed from the Genesis 11's hermeneutics. In return, a world of a benevolent nature and of immer-jetzt cultural identities is presented: the human selfconstruction of spaces and times is still fought or denied but in front of it, there are new 
opposites and new opponents. The diagram (Figure 1) was designed to represent, in a very simplified way, the different legacies of Genesis 11 , that is to say 'God's view' on Babel.

In short, the central zone of the graph displays mainstream religious attitudes that have progressively neglected the urban component of the myth; for the apparently more flexible ones, the normative character of the initial text has been progressively erased. However, we will find this dimension in two more external kinds of statements. Aside from the religious debate, the left part of the diagram is probably the most influential. Immanence emerges as an alternative to a weakened transcendence (see the 'Switch' line on the diagram, Figure 1). It is twofold.

First, the anti-societal libertarian stance sees the city as the perfect example of a superimposed societality. As for the neonaturalist ideologies, they have changed the 'car body' but have retrieved and reused the mechanical engineering of the Babel myth, and have carried out a 'standard exchange' of the 'parts' from the transcendent engine to the immanent one.

Second, some ideologies can be rooted in Jean-Jacques Rousseau's thought (1761) when he very clearly explained all sorts of bad things he ascribed to urban 'artificiality' in comparison with rural 'authenticity'. Later, most totalitarianisms of Fascist (in particular German Nazism or the Vichy French state) or Communist (especially Maoism, Enver Hoxha or Khmer Rouge regimes, and, more implicitly, Stalinism) families developed hate towards the city as a rejection of a self-organised political society, with its autonomous individuals, its indomitable creativity, its strong civil society and its political pluralism. More specifically in the United States, renowned intellectuals have more or less viewed the city as a mistake or as a sin (Orsi, 1999). In the same country but from a quite different point of view, the Libertarian movement basically rejects the taxes, governments, disciplines, and social relationships that any city requires.

Beyond formalised ideologies and state policies, the cocktail of anti-urban 'puritan' ideologies and anti-societal libertarianism has generated the well documented 'urban flight' and manufactured a significant part of $20^{\text {th }}$ century's human settlements called Suburbia in North America (Vaetisi, 2013) and peri-urbanisation in Europe. These personal and political choices in favour of 'counterurbanisation' spatial configurations aim at taking advantage of urban concentrations while entrenching themselves in gated, semicommunal, corporatist communities. However, in the last decades, these massive practices have apparently ceased to have a substantial theoretical counterpart.

The purpose of this text is not only to identify genealogies of speeches and meanings, but also to investigate how far the arrival points do match contemporary attitudes and practices. The last two sections explore the two sides of this 'immanent turn' and their possible junctions.

\section{Libertarian Immanence: voting with one's feet}

In major city centres, bobos ('bourgeoisbohemian', people enjoying a high level of both cultural and economic capital) cohabit with migrants and 'pobos' ('poor-bohemian', 
people with much cultural capital and little economic capital who are willing to spend a lot to live in central neighbourhoods of large cities). Bobos and pobos confirmed their attachment to urban life in the 1970s in Western Europe and in the 1980s in North America. Meanwhile, many medium-income dwellers have chosen to leave the centres to accomplish the suburban/peri-urban dream (bungalow + property ownership + car + garden). This 'urban flight' began back in the early $20^{\text {th }}$ century in North America, but it is mostly a post-World War II process in Europe. Another difference derives from the better resistance, in Europe, to the destruction of historical districts by 'Modern Movement' inspired urban projects. The late $20^{\text {th }}$ century shows an acceleration of this process on both sides of the Atlantic. Since then, there has been something like a two-way crossover of activities and people that need a high-intensity urban environment and activities and people that do not need it or simply reject it.

\section{Arbitration on inhabiting models}

This convergence has of course strong effects on the desirability of urban space. Urban cores can be extended to neighbouring areas (such as West Brooklyn or West New Jersey in New York) but the pressure on real estate prices in central areas is dramatic. However, at odds with an abundant literature about 'gentrification', social mix has either increased (due to the decline of inner-city ghettos) or has been maintained in some other neighbourhoods by the arbitration, as expansive as it can be, in favour of a city-centre dwelling. In European cities, public social housing policies have also partially compensated the growth in the soil price by supporting medium- and low-income inhabitants and preserving both sociological and functional diversity. As a result, central areas of cities, and all the more in the big ones, are undoubtedly more mixed than any other gradient of urbanity.

These alternatives create a new geography. Significant inequalities in the opportunity of living the model of inhabiting of one's choice do persist. However, it is undeniable that the current map of population distribution is gradually overlaying this population's desires. Said differently, fewer people are forced to live in a 'spatial style', that is, in an urbanity gradient (Lévy \& Lussault, 2013) they do not like. It is therefore not by chance that such a strategic choice, the way of inhabiting (where and how I would like to live), meets another strategic choice, the political orientation (what values and horizons I would like for society).

\section{A gaping spatial political divide}

The following maps show recent electoral geographies in Switzerland, Britain, Austria, France and the United States. In each case, it opposes 'progressive' to 'populist' voters.

The phenomenon is massive and pervasive in the West (Lévy, 2017). In Europe, almost every country shows the following pattern: In city centres, mainly in metropolises, voters choose openness to public space, public goods, European construction, and globalisation, while, in suburban or periurban gradients, nationalism and rejection of any kind of otherness prevail. The prevalence of this pattern is so strong that it has been possible to formalise it in a simple modelling equation (Lévy, 2020a). 
Figure 2 - February 2014 swiss 'against mass immigration' referendum

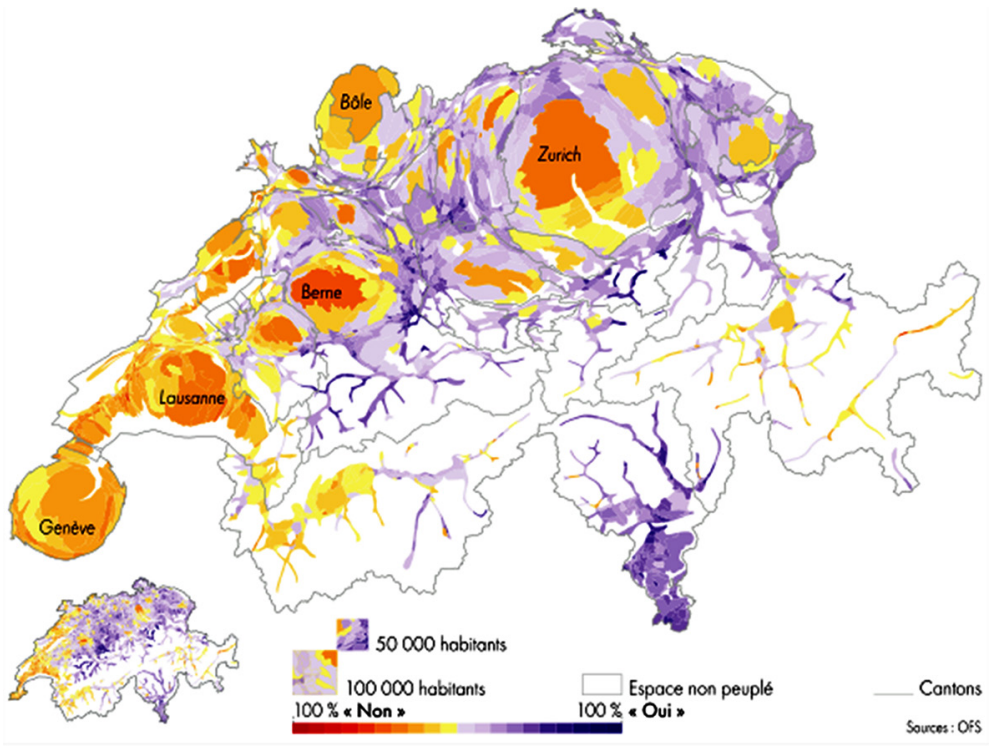

Differentiated cartogram (population). Source: Lévy, 2017.

Figure 3 - June 2016 'Brexit' Referendum

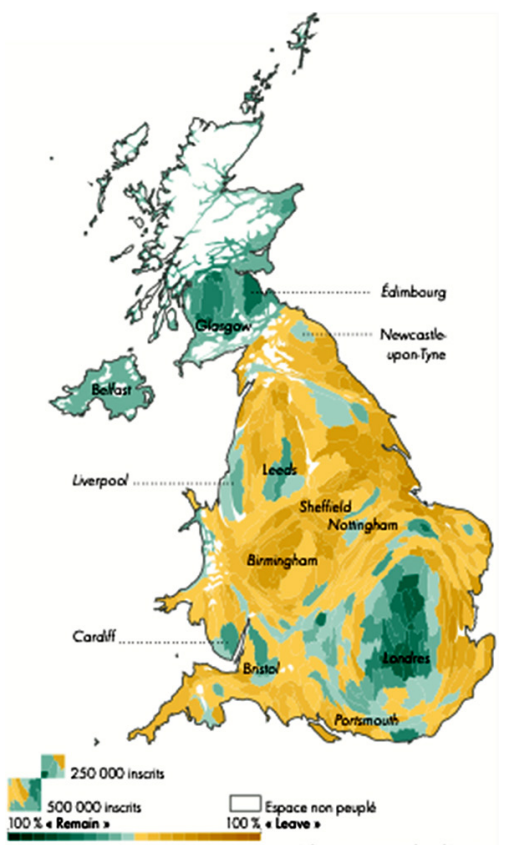

Cartogram (population). Source: Lévy, 2017. 
Figure 4 - December 2016 - Austrian Presidential Election (round 2)

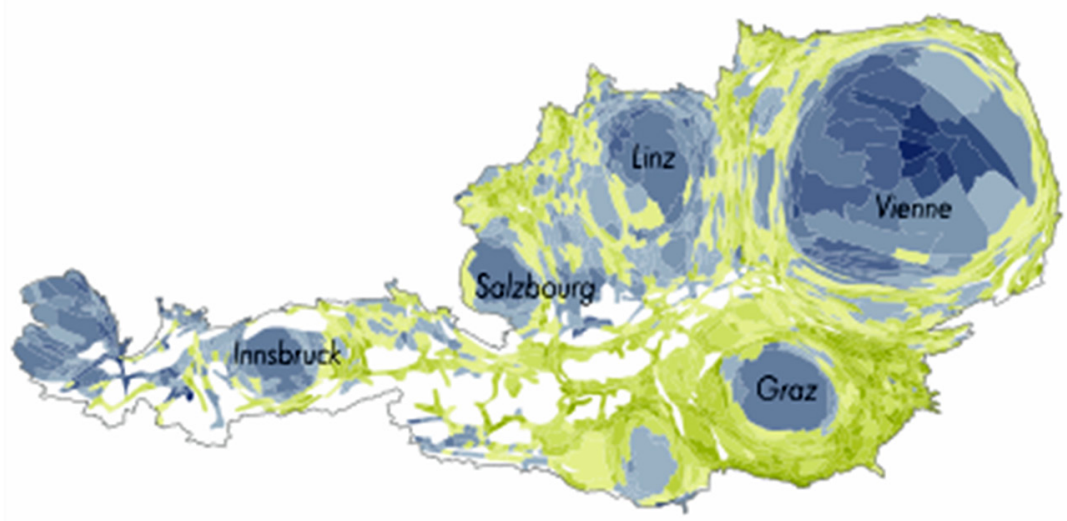

50000 inscrits

100000 inscrits $100 \%$ Alexander Van der Bellen
Espoce non peuplé $100 \%$ Norbert Hofer

Sources : Bundesministrerum tir hneves; dalagrat

Differentiated cartogram (population). Source: Lévy, 2017.

Figure 5 - April 2017 - French Presidential Election (round 1)

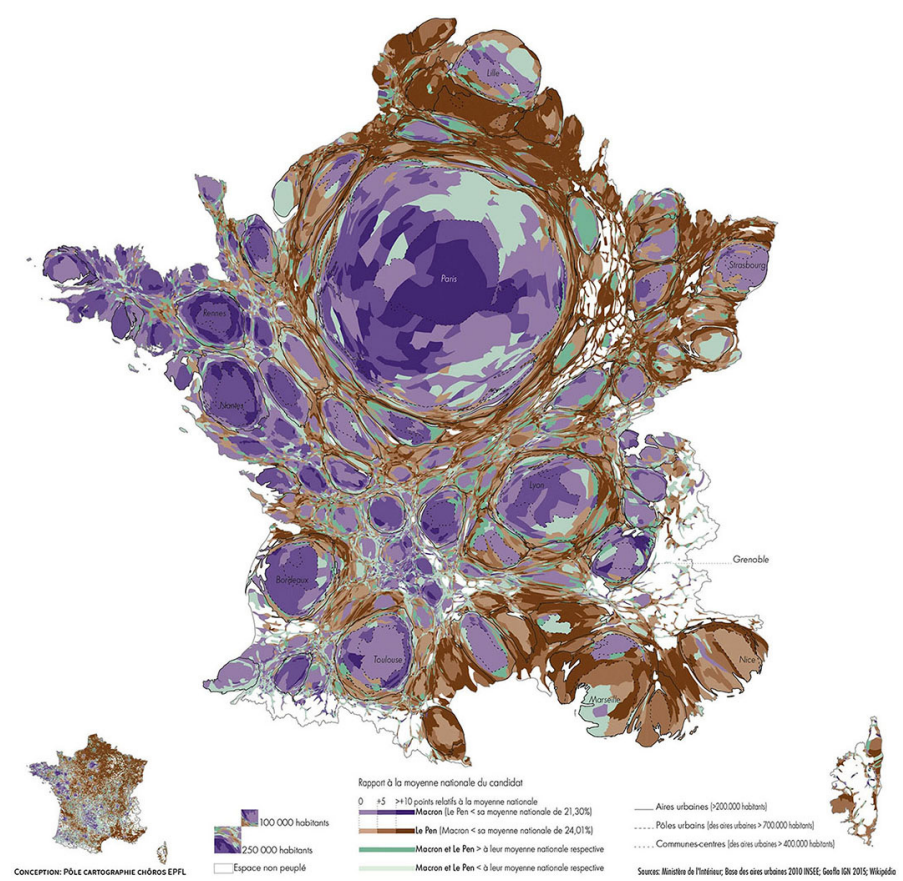

Differentiated cartogram (population) and Euclidean maps. Source: Lévy, 2017. 
Figure 6 - November 2020 US Presidential Election

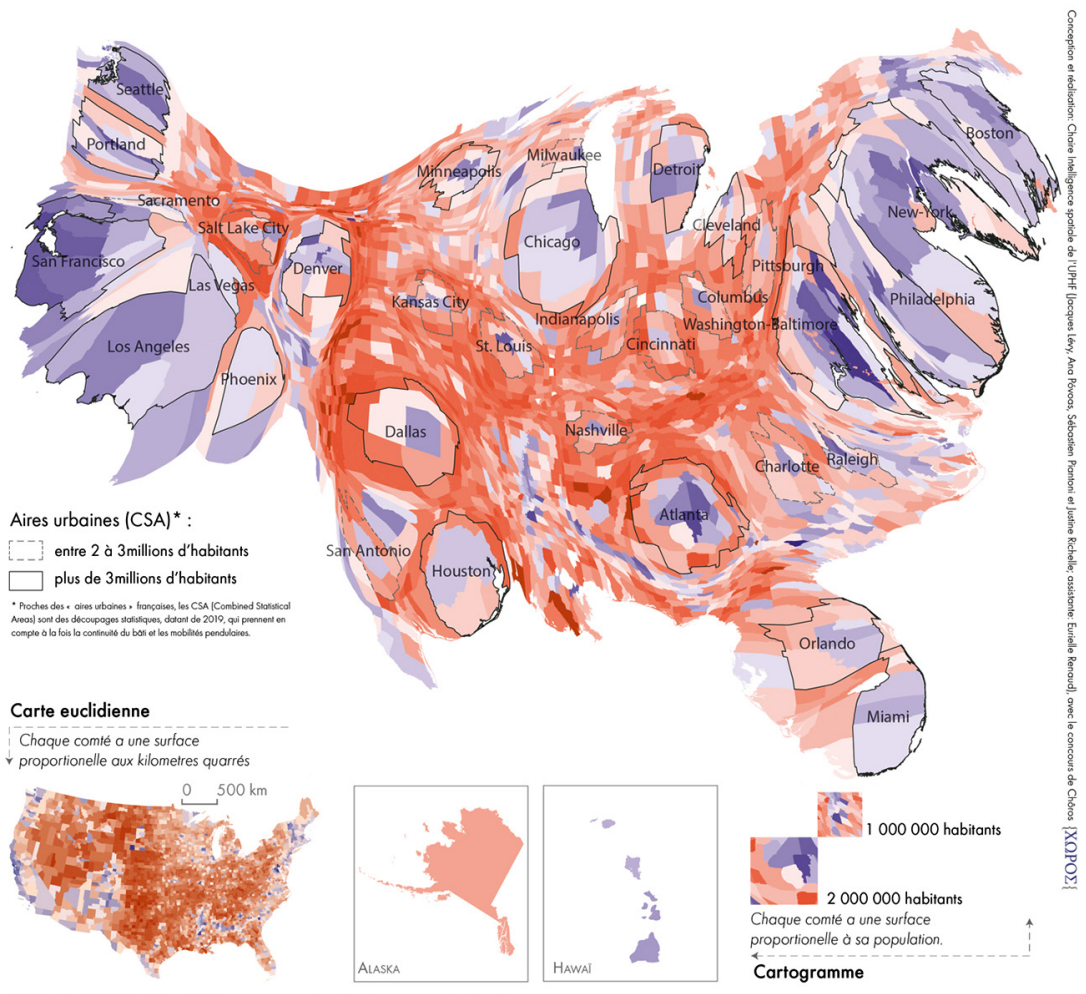

Pour le républicain Donald Trump Pour le démocrate Joe Biden Résultats par comtés à l'élection présidentielle américaine $100 \%$

$100 \%$ décompte partiel au 5 novembre $(11 \mathrm{~h} 30$, heure de Paris)

Cartogram (population) and Euclidean maps. Source: Lévy et al., 2020. 


\section{Novel Issues for Spatial Justice}

Many 'populist' voters nostalgically refer to a golden age of good wages and pervasive public utilities. Are those voters less equipped with social amenities compared to the others? Have the places they inhabit been 'abandoned' by public policies? It is far from evident. By and large, the inhabitants of urban fringes in the American Suburbia or in European peri-urban areas are wealthier than those who live in the city centres. However, many citizens living off built-up areas express a feeling of having been left behind and fuel 'populist' politicians epitomised by Donald Trump in the United States and powerful nationalist-xenophobic movements in Europe.

First of all, new geographical freedoms have largely diffused throughout a large part of developed societies. Mobility has become faster and housing is, in relative terms, cheaper than it used to be in the first half of the $20^{\text {th }}$ century. This dual solvability has changed the context of individual spatial strategies, increasing the range of alternatives. In large cities, there is a certain economic neutrality in the housing + mobility budget block between inner and outer locations: in the centres, you pay much more for the property but less for mobility, thanks to the public transport system, and the opposite prevails as you move away from core areas. Other parameters such as apartment/house, ownership/tenancy and, more and more, family style options have appeared on individual dashboards. There is a large 'middle group' that must and can operate these arbitrations, an 'upper group' for which it is not necessary and a 'lower group' for which it is not possible.

This situation can be summed up by saying that the desire to flee the city has been made possible for a large part of the inhabitants of the West. The outcome of this new freedom is that a new or old dream has been fulfilled. If motivations vary, many studies converge to relate the choice of the huge majority of these suburban/peri-urban dwellers to some expectations. The possibility of selecting one's neighbours, the "calm" deriving from sociological homogeneity, the functional separation of spaces, and the privatisation of daily life and mobility can be mentioned. These wishes set up an almost pure negative definition of urbanity.

These maps do not prompt to adopt a new spatial structuralism that would replace the old, economic one. There is by no means a mechanical effect of a place's objective conditions on the votes. By and large, in every single European or North American city, the neighbourhoods where populist xenophobes get a maximum of votes are not those where strangers are most numerous, much to the contrary. The spatial dimension of this new social dynamics encompasses a fully-fledged political component. Today, these freer inhabitants are simultaneously stronger citizens. 


\section{Neonaturalist immanence: Babel in times of pandemic}

The 2020 pandemic has given an opportunity for an emerging current to specify its views and to radicalise a previously mentioned statement: everything negative coming from nature should be seen as a punishment for the dire behaviour of humans. Recent and older texts published by French philosophers Dominique Bourg and Bruno Latour lead to the conclusion (Lévy, 2020) that the different components of the converging part of their approach (they also show differences) sketch a consistent cognitive, moral, political and religious picture where the virus is a benevolent oracle of the coming apocalypse and humans are pathogenic agents, and where the reference of the desirable political system is not democracy anymore; it is Carl Schmitt's thought. To Bourg, the pandemic is "nature's last warning" and, to Latour, the "Terrestrials" (on whose side he himself stands) are involved in a titanic life-and-death struggle against the "Humans". To both, the ideas of progress, emancipation, development and Enlightenment should be forever condemned and discarded. To both, a religious surge based on immanence is the right response to the present-day situation.

This viewpoint is not new. Any religion based on transcendence has always included (or has had to include) a large array of realities (objects, characters, environments, situations and events) rooted in concrete life to make their speech understandable and appropriable by the ordinary worshipper. Nevertheless, the particular configuration of the intellectual stage in the West during centuries has put the emphasis on metaphysical ontologies, on an anthropomorphic God, and on a sovereign Subject, neglecting alternative frameworks. In the philosophical profusion of the $18^{\text {th }}$ century, substantial aspects of Rousseau's and Johann Gottlieb Fichte's thought - and in his wake, all the 'German romanticism' -, overarched by an immanent approach to nature and the sacred, were marginalised. For two centuries, naturalism was a resource deeply anchored in social worlds, but which remained theoretically a sleeping, 'outsider' concept. We can therefore call neonaturalism the corpus of ideas whose emergence has accompanied (as inspiration or development) the ecological awareness movement of the late $20^{\text {th }}$ century.

In the foreground, we can identify some philosophers such as Martin Heidegger, Hans Jonas and their disciples, or difficult-toclassify characters like Bruno Latour. In the background, a vast nebula of 'collapsologists', radical misanthropic Anarchists or rural fundamentalists who, together with 'front office' thinkers, are sketching the new landscape of the contemporary reactionary thought. The Covid-19 pandemic has made convergences between persons and group more visible, as well as the religious component of some orientations.

In the first phase of the epidemic in the West (March-April 2020), the key move was to tag the virus as a side effect of the 'climatic crisis'. The pandemic would be a forerunner of future, even worse climatic events. In the case of climate and also of epidemics, 
humans would be guilty of having perpetrated similar abuses on natural environments. This rationally disputable coupling can be seen as a try to divert the political resource coming from fear of the virus and from the capability, shown by the World's societies, for carrying out massive and courageous public policies. Why so much for the coronavirus and so little for the climate?, some have complained. The urban dimension was not emphasised by these authors in that period, but examples of a junction between neonaturalist and anti-societal immanence show that the construction of a common framework giving a pivotal role to space-centred approaches and to Babel's ideological heritage is in progress.

\section{A Junction}

This novel framework makes possible a rapprochement between the left and the right section of the diagram (Figure 1), as signalled by the 'Bridge' arrows.

At different stages of his life, Alberto Magnaghi has followed, in a way, Friedrich Engels' itinerary from Die Lage der arbeitenden Klasse in England [Condition of the Working Class in England] (1845) to Zur Wohnungsfrage [The Housing Question] (1872). He began with the denunciation of the capitalist city to challenge, at the end of the day, the idea of city itself.

Magnaghi proposes an organisation of bioregioni urbane, that is to say, a redistricting of local and regional societies based on orographic and hydrographic configurations. In this perspective, the rule would be to accept a maximum of 300,000 people in each human settlement, an agenda that requires to partially empty many existing urban areas. Magnaghi sides with a group of authors in search of an optimal mass for 'human-size' cities, which is generally the signature of a reluctance towards any city. "My current major concern is how to prevent the urbanisation of the world", Magnaghi (2016) confesses. In a recent text signed by Bourg and other authors (Bourg et al., 2020), the same idea with the same 300,000 -threshold appears. The relation to Genesis 11 is detectable: a city that could grow without mass constraint is presented as a typical expression of hubris. With Magnaghi, we have a first insight of the possible relationships between neonaturalism and antiurban ideologies.

This is also a first gateway with Puritan or Libertarian views. This connection becomes clearer with the second example. Like Magnaghi, Kirkpatrick Sale (1985) is a partisan of 'bioregionalism', a political scheme based on the autarky of small 'natural' spatial units.

Sale undoubtedly belongs to the North American 'deep ecology' current, inspired by Henry David Thoreau, John Muir, Frederick Jackson Turner, Rachel Carson, and various protagonists of the American lyric naturalism. However, he has also been labelled 'Neo-Luddite' because he encourages the destruction of machines or other means of production as symbols of capitalist exploitation. Finally, Sale is a prominent figure of secessionism - the claim that any person or group is legitimately entitled to opt out of a larger political entity -, which is a figurehead of US Libertarian parties' programmes. 
The link between the left and the right part of the chart operates thanks to the bypassing of the former mainstream, transcendent block. Conversely, the 'immanent' party moves up to the frontline against the city, the society, and humans as a whole.

We are observing both a religious turn in some political movements and an immanent turn in the religious constellation of the West. This dual change has also had an impact on the biggest institutions. A slow evolution can thus be perceived in Pope Francis' speech towards attacking more directly not only the immoral collateral effects of development, like social injustice, but the idea of progress. This is visible in his 2015 Encyclical Laudato si, following the first moves made by John Paul II (see, for example, the 1991 Encyclical Centesimus Annus). A significant French Jesuit author, François Euvé (2020), recently proposed a strategic shift that could be a trial balloon for a general move of the Catholic Church: he blames the "libido dominandi" the humans apply to biophysical worlds and their "ecological sins", and sums up his view in this motto: "Any misconduct against nature is a misconduct against God". He also rejects the traditional "overhanging stance" of the Church and suggests this switch is the only way for Catholics to regain its lost legitimacy. The major change is that the "anthropocentrism" he denounces is not about rivalry with God anymore; it is rivalry with other creatures, an attitude that is generally not - this is an understatement - the dominant speech of the Jewish-Christian religious corpus in the West. The classic argument that couples human responsibility and religion (Man was created by God in His image and that is why Man is accountable in His face) has seemingly become obsolete. The referent and criterion of human responsibility have become, from this moment onwards, Nature, linked by mere indirect ties to an almighty but absent God. Since the Renaissance's science and philosophy, God has left the rational world of causes; He is now leaving the moral world of commandments. The problem with Babel is not any more the too effective selforganisation of societies, but the very fact that humans are intrinsically dangerous.

The baton of Genesis 11 has been passed in an unexpected way. The new runners do not fit the model of a hierarchised and disciplined army that state-like institutional churches have long epitomised. Although they generate intricate, rippling, and unstable networks, they are potentially capable of mobilising militants and multitudes. These unruly, sometimes sloppy soldiers fiercely continue the Divinity v. Humanity combat.

This continuity gives an unparalleled role to urbanity. As self-organised, massive human artefacts, the cities deserve the blame of hubris. As a combination of density and diversity, they present the same level of exposure to otherness as the World itself and they provide the opportunity - exactly the same opportunity found in Genesis 11 - to gather the hate for urbanisation and globalisation in the same bundle. Finally, as places of emancipation from communal allegiances, they are the evident target of 'illiberal', anti-Enlightenment currents. 


\section{The Fable of Babel}

I would like to conclude by presenting a plea for a citizen science (see Chôros, 2018; Chôros, 2020). Juxtaposed to 'science', 'citizen' would by no means introduce any restriction to the free, independent, incorruptible search for truth that defines scientific research. It is the exact opposite of the enslaved information of big, holistic ideological systems that oppose 'proletarian' to 'bourgeois' sciences or pretend to hierarchise research outcomes through the point of view of the author's 'positionality'. A citizen scientist simply does not forget that there is knowledge production outside academia. He or she admits that other citizens do not need 'professors' of ethics or political 'pedagogy'. He or she is aware that what is at stake in public debate is a matter for all citizens, not only for 'experts'. That is why I am happy to borrow my last words from Stefan
Zweig (1916a; 1916b). His fable-like story has been published almost simultaneously in a French-speaking and in a German-speaking journal in the vortex of World War I. In the conclusion, he opens a new chapter in the Babel 'novel':

The confusion which God instilled in souls is still too great, it may be years before the brethren of yore work again in peaceful competition with eternity. But we must go back to the edifice, each one to the place he left in the moment of confusion. Perhaps we shall not see one another at work for years, perhaps we shall rarely hear from one another. But we get down to work now, each at his post, with the old ardour, the tower will rise again, and on the heights the nations will meet again. (Zweig, 1962)

This prophecy shows that the myth of Babel is still a promising raw material for civic agency.

\section{[I] https://orcid.org/0000-0003-3182-3731}

Université Polytechnique Hauts-de-France, Spatial Intelligence Chair, Campus Tertiales. Valenciennes, France, European Union.

Chôros rhizome: www. choros.place (Amiens, Brussels, Fribourg, Geneva, Kuwait, Lausanne, London, Lille, Paris, Reims, São Paulo, Valenciennes).

jacques.levy@choros.place

\section{Acknowledgement}

This work has been made possible by the Max Weber Centre for Advanced Cultural and Social Studies (Kolleg-Forschungsgruppe 'Religion and Urbanity'), University of Erfurt, in which the author was hosted as a fellow in Spring 2020. 


\section{References}

BOURG, D. et al. (2020). Propositions pour un retour sur terre. Good Planet Mag', Agril 16. Available at: <https://www.goodplanet.info/2020/04/16/propositions-pour-un-retour-sur-terre/>. Access on: April 16, 2020

CHÔROS (2018). Manifeste. Available at: <https://www.choros.place/manifeste>. Access on: February $1,2021$.

(2020). La science citoyenne et la démocratie interactive pour gouverner l'incertain. Le Monde, 8 May. Available at: <https://journal.lemonde.fr/data/821/reader/reader.html?t=15888652973 40\#!preferred/0/package/821/pub/1159/page/30>. Access on: February 1, 2021.

EUVÉ, F. (2019). L'anthopocentrisme modern a contaminé le christianisme. Le Monde, 24 December. Available at: https://www.lemonde.fr/idees/article/2019/12/24/francois-euve-Ianthropocentrisme-moderne-a-contamine-le-christianisme_6023928_3232.html. Access on: February 1, 2021.

HARLAND, P. J. (1998). Vertical or Horizontal: the Sin of Babel. Vetus Testamentum, v. 48, n. 4, pp. 515-533.

HIEBERT, T. (2007). The Tower of Babel and the origin of the world's cultures. Journal of Biblical Literature, v. 126, n. 1, pp. 29-58.

KASS, L. R. (1989). What's Wrong with Babel. The American Scholar, v. 58, n. 1, pp. 41-60.

LÉVY, J. (1994). L'espace légitime. Paris, Presses de Sciences Po.

(ed.) (2017). Atlas politique de la France. Paris, Autrement.

(2019). Which Urbanity Is Babel the Name of?", fellowship research programme. Erfurt, MaxWeber-Kolleg.

(2020a). Ce dont on peut parler, il faut le dire. Les mutations de l'espace politique et ses enjeux. EspacesTemps.net, January. Available at: https://www.espacestemps.net/en/articles/ce-donton-peut-parler-il-faut-le-dire/ Access on: February 1, 2021.

(2020b). Les prophètes de l'immanence. Le coronavirus au prisme du néonaturalisme. EspacesTemps.net, April. Available at: https://www.espacestemps.net/articles/les-prophetesde-limmanence/. Access on: February 1, 2021.

LÉVY, J. \& LUSSAULT, M. (eds.) (2013). Dictionnaire de la géographie et de l'espace des sociétés. Paris, Belin, new edition.

LÉVY, J. et al. (2020). Topologies politiques. Espace politique et dynamique sociale après l'élection présidentielle américaine de 2020, [co-published by] Le Grand Continent; EspacesTemps.net, December.

MAGNAGHI, A. (2016). "Dalla città fabbrica al pianeta degli slum", cycle Sguardi sulla città, lecture, 26 May. Calusca bookshop, Milan. Available at: https://www.youtube.com/watch?v=aO5b_ QoVdsA. Access on: February 1, 2021.

ORSI, R. (1999). Gods of the City. Bloomington, Indiana University Press.

ROUSSEAU, J.-J. (1761). Julie ou la Nouvelle Héloïse. Amsterdam, Marc-Michel Rey. 
SALE, K. (1985). The Bioregional Vision. San Francisco, Sierra Club.

VAETISI, S. (2013). Anti-urban ideologies and practices in the evolution of the American City. Antiurbanism in America. Transylvanian Review, v. XXII, n .3, pp. 82-95.

WHITE, M. \& WHITE, L. P. (1962). Intellectual versus the City. From Thomas Jefferson to Frank Lloyd Wright. Cambridge, Harvard University Press.

ZWEIG, S. (1916a). La tour de Babel. Genève, Le Carmel.

(1916b). Der Turm zu Babel. Berlin, Vossiche Zeitung.

(1962). The Tower of Babel, translation from Zweig, 1916b, Judaism Quaterly, v. 9-4, pp. 3-5.

Received: September 8, 2020

Approved: November 9, 2020 
